\title{
Down-hole geophysical characterization of middle-upper Quaternary sequences in the Apennine Foredeep, Mirabello, Italy
}

\author{
${ }^{1}$ Geotema srl, University of Ferrara spin-off company, Ferrara, Italy \\ ${ }^{2}$ Istituto Nazionale di Geofisica e Vulcanologia, Sezione Roma 1, L'Aquila, Italy \\ ${ }^{3}$ Istituto Nazionale di Geofisica e Vulcanologia, Sezione Roma 1, Bologna, Italy \\ ${ }^{4}$ Università di Ferrara, Dipartimento di Architettura, Ferrara, Italy \\ ${ }^{5}$ Progeo srl, Forli, Italy
}

Luca Minarelli ${ }^{1{ }^{\star}}$, Sara Amoroso ${ }^{2}$, Gabriele Tarabusi ${ }^{3}$, Marco Stefani ${ }^{4}$, Gabriele Pulelli ${ }^{5}$

\section{Article history}

Received July 14, 2016; accepted October 6, 2016.

Subject classification:

Shear wave velocity, Deep geophysical test, 2012 Emilia earthquake, Emilia-Romagna stratigrafic units, Active tectonics.

\begin{abstract}
The 2012 earthquakes sequence stroke $a$ wide area of the alluvial plain in the Emilia-Romagna Region and triggered a new research interest on the role of the subsurface stratigraphic architecture and petrophysical property distribution in the modulation of the local seismic effects. Few direct shear wave velocity $V_{S}$ data were however available below the depth of $50 \mathrm{~m}$. The only available $V_{S}$ measurements were obtained from an anticline area, characterized by a reduced stratigraphic thickness and peculiar sedimentary facies, hardly representative of the majority of the alluvial plain subsurface. The study provides the first $V_{S}$ profile available from middle-upper Quaternary successions deposited into a fast subsiding syncline area of the Apennine Foredeep Basin. The P-wave velocity $V_{P}$ and the $S$-wave velocity $V_{S} \operatorname{logs}$ fill in the previous data gap on the geophysical parameters needed for the estimation of the local seismic response. Both $V_{P}$ and $V_{S}$ logs were continuously acquired to the depth of $265 \mathrm{~m}$. The log records a velocity increase with depth, punctuated by sharp increases at some stratigraphic discordance surfaces. The value of $800 \mathrm{~m} / \mathrm{s}$ that characterizes the "seismic bedrock", as defined by the Italian building code [NTC 2008] was never reached at any depth. The investigated succession records a depositional evolution from deltaic-marine to alluvial plain conditions, punctuated by six glacio-eustatic depositional cycles, developed in Middle-Upper Quaternary times. The stratigraphic units described in the syncline log were correlated at a regional scale, with the thinner anticline succession of Mirandola. Correlatable units deposited into syncline and anticline areas reveal similar shear wave velocity values, supporting the regional extrapolation of the measured values.
\end{abstract}

\section{Introduction}

In May 2012, several medium-large earthquakes impacted on a wide portion of the alluvial plain of northern Italy (Figure 1), belonging to the Lombardy, Veneto and Emilia-Romagna regions. The strongest earth- quake $\left(M_{L}\right.$ 5.9) occurred close to Finale Emilia, while the second largest one $\left(M_{L} 5.8\right)$ took place near Mirandola [Pondrelli et al. 2012]. The causative faults belong to the Ferrara Arc thrust system [Bonini et al. 2014, DISS Working Group 2015], forming the external portion of the Apennines Chain (Figure 1). The earthquake effects were modulated by the changing seismic amplification, associated with the largely variable PlioPleistocene successions [GeoMol Team 2015]. The thickness of the post-Miocene units varies from several kilometres in syncline areas, to $200 \mathrm{~m}$, in anticline zones, near Mirandola and Casaglia (Figure 1). Large lateral variations in stratigraphic thickness are visible also within the upper Quaternary units [GeoMol Team 2015]. The seismic acceleration induced pervasive sand liquefaction phenomena within Holocene fluvial bodies [Caputo and Papathanasiou 2012, Papathanassiou et al. 2012, Emergeo Working Group 2013].

The 2012 earthquakes triggered a widespread interest on the seismic hazard assessment in the alluvial plain area of the Emilia-Romagna Region [Di Manna et al. 2012, Malagnini et al. 2012, Meletti et al. 2012, Milana et al. 2014, Papathanassiou et al. 2015, Tonni et al. 2015]. The available data on the subsurface were however scanty. The regional administration therefore collected many previously performed shallow logs, such as cone penetration tests, stratigraphic corings and water well stratigraphies, available from the shallow subsurface, and performed several new investigations, reaching an average depth of 30-50 m [Martelli and Romani 2013]. Only few data were however available from deeper levels. A measurement of the shear wave veloc- 


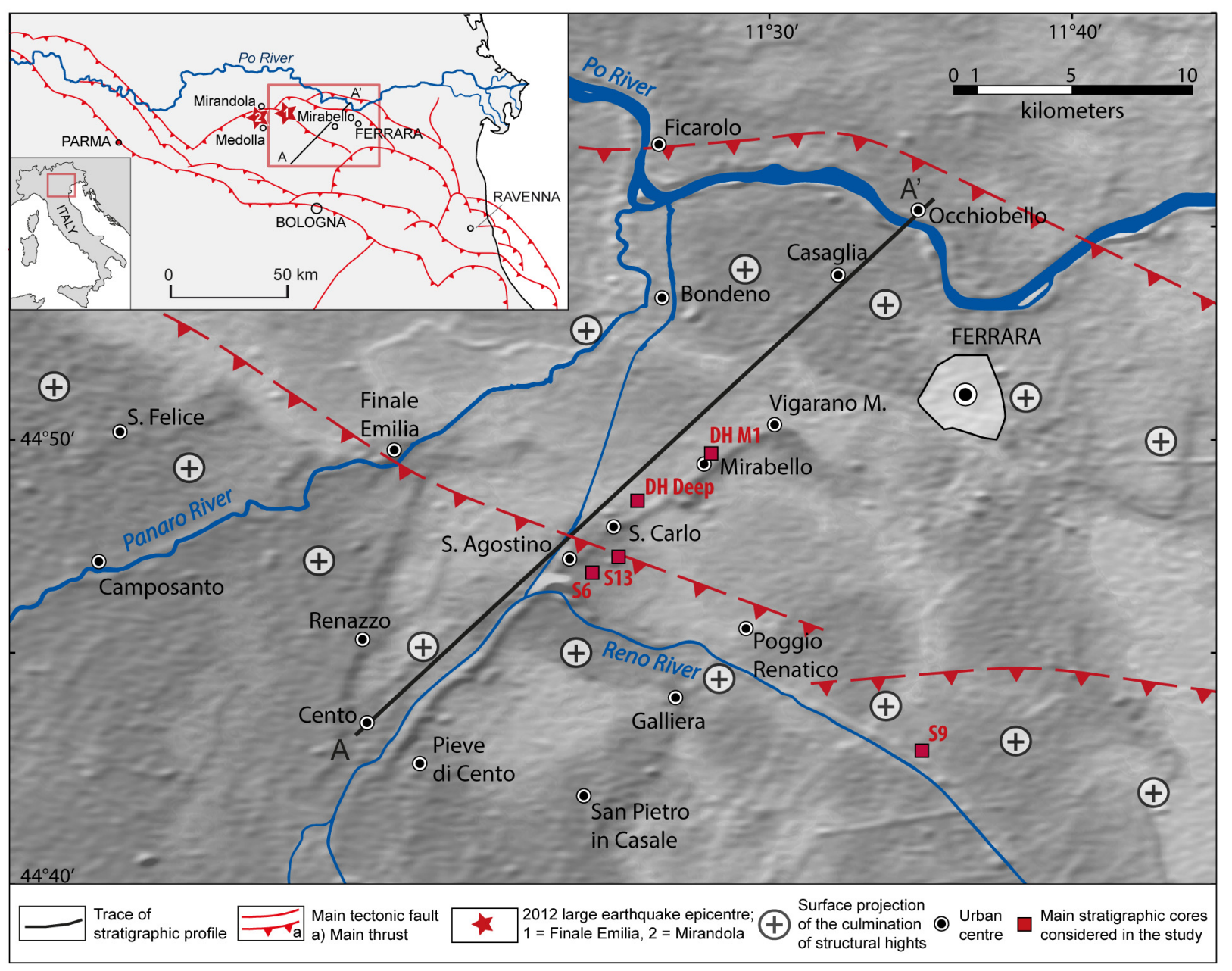

Figure 1. Altimetry map of the study alluvial plain area with the position of the discussed logs. Some of the major subsurface overthrusts are schematically illustrated. The line A-A' depicts the location of the geological profile of Figure 2.

ity $V_{S}$ was not normally available at depths exceeding 30-50 m. A crucial parameter for the estimation of the local amplification was thus widely lacking. Direct $V_{S}$ measurements exceeding the depth of $50 \mathrm{~m}$ were acquired only at two sites, near Medolla and Mirandola (Figure 1), down to the depths of $101 \mathrm{~m}$ and $127 \mathrm{~m}$ respectively [Martelli and Romani 2013, Paolucci et al. 2015, Garofalo et al. 2016]. These two sites are less than $4 \mathrm{~km}$ apart and belong to an anticline area [Tarabusi and Caputo 2016]. The logs therefore show comparatively thin stratigraphic successions, with sedimentary facies quite different from those accumulated into the vast majority of the Emilia-Romagna Region (Figure 2).

The extrapolation of the aforementioned geophysical data to the thick successions accumulated into the syncline areas was therefore uncertain. Direct $V_{S}$ measurements from syncline regions were clearly needed to improve the accuracy of the local seismic response studies. The present research, for the first time, provides a $V_{S}$ distribution acquired from a deep down-hole test carried out in a syncline area. The investigation was performed in the middle-upper Quaternary succession accumulated into the fast subsiding syncline zone south- west of Ferrara, between the villages of Mirabello and San Carlo (Figure 1).

\section{Structural and stratigraphic framework}

The study area belongs to the external part of the Apennines Chain, buried beneath the recent alluvial plain. This portion of the chain consists of blind thrust and fold structures [Pieri and Groppi 1981, Boccaletti et al. 2004], generated through Neogene and Quaternary times [Ghielmi et al. 2013, Vannoli et al. 2015]. The fast regional subsidence of the southern portion of the foredeep basin is superposed to the ongoing fault-fold deformation [Carminati et al. 2010]. The syncline areas thus record much larger subsidence values than the anticline ones. The lateral variation of the subsidence rate strongly influenced the stratigraphic thickness (Figure 2), the sedimentary facies architecture and the petrophysical parameters distribution [Bigi et al. 1992] and thus the seismic wave propagation properties of the Plio-Pleistocene units. The Quaternary of the region records the impact of active tectonic deformation and of massive climatic and eustatic fluctuations. The whole of these factors induced key stratigraphic 


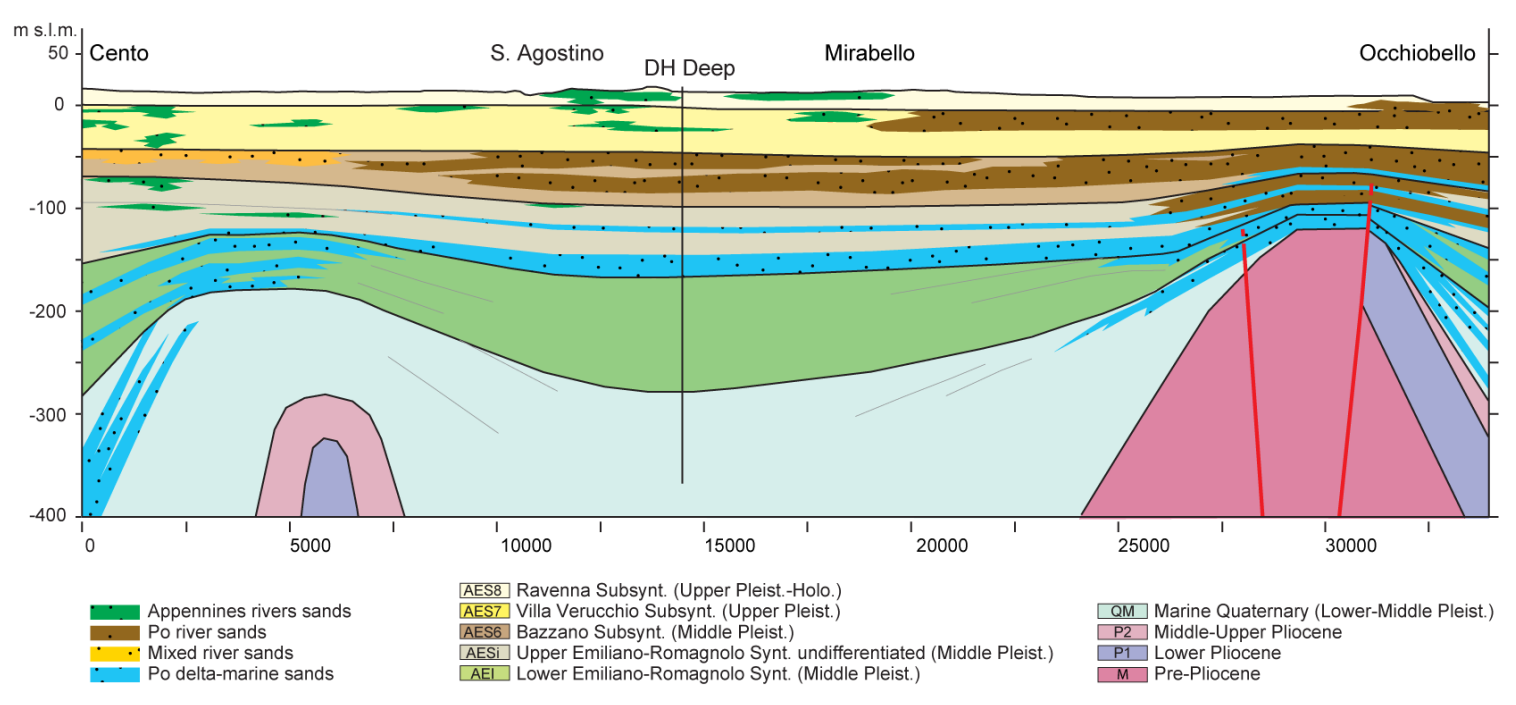

Figure 2. Geological cross section interpreting the first $400 \mathrm{~m}$ of subsurface between Cento and Occhiobello. The impact of the active tectonic deformation and the associated differential sediment compaction on the stratigraphic geometry is clearly visible. Vertical exaggeration $\times 25$ (modified after Martelli and Romani [2013], Paolucci et al. [2015]).

surfaces that support the subdivision of the sedimentary successions into allostratigraphy units, organized in different hierarchical levels [Regione Emilia-Romagna et al. 1998]. Two main synthems are separated by a discordance surface, associated with a structural reorganization of the foredeep basin area. The synthems are further subdivided into a number of subsynthems (Figure 2), recording the large glacio-eustatic and climatic fluctuations. The transgressive surfaces induced by the eustatic rises associated to deglaciation were chosen as the subsynthem basis. The base of each subsynthem unit corresponds to the deactivation of the synglacial coarse-grained sedimentation, accumulated into middle alluvial plain environments. Syn-transgressive units are capped by organic-rich marsh mud, deposited into lower alluvial plain settings, or, in the deeper portions of the successions, by marine-deltaic sediments. The regressive trend of the alluvial plain successions culminates into a new interval of synglacial lowstand sands. The ongoing transgressive-regressive cycle has been ascribed to the Ravenna Subsynthem (AES8), the base of which correlates with the Stage 1 of the global Marine Oxygen Isotope curve [Martinson et al. 1987], corresponding to the base of the Holocene (about $14 \mathrm{ka}$ ). The lower boundary of the underlying Villa Verucchio Subsynthem (AES7) is assigned to the Marine Oxygen Isotope Stage M.O.I.S. 5e, (about $120 \mathrm{ka}$ ) whereas the base of the previous Bazzano Subsynthem (AES6) correlates with M.O.I.S. 7 (about $240 \mathrm{ka}$ ). Moving downwards, two further depositional cycles are ascribed to the undivided lower portion (AESi) of the Upper Emiliano-Romagnolo Synthem and lack a formal stratigraphic terminology. The Lower Emiliano-Romagnolo Synthem shows several transgressive-regressive pulses, recording a globally shallowing evolution.

\section{Data acquisition methodology}

The Mirabello drill (Latitude: $44.8100^{\circ}$; Longitude: $11.4264^{\circ}$ WGS84) crossed a middle-upper Quaternary succession, reaching a depth of $372 \mathrm{~m}$. The deep borehole was used to perform a down-hole test, hereafter named DH Deep. Both compressional $\left(V_{P}\right)$ and $\operatorname{shear}\left(V_{S}\right)$ wave velocities were measured, down to the depth of 265 $\mathrm{m}$. Figure 3 shows a schematic plan layout of the seismic sources, surface geophones and the core location.

A grout mixture was pumped into the core and a PVC pipe, with an internal diameter of $162.8 \mathrm{~mm}$, was installed, down to $265 \mathrm{~m}$. An additional steel casing, with an internal diameter of $263 \mathrm{~mm}$, was emplaced in the upper $18 \mathrm{~m}$. Three different seismic sources were used (Figure 4): an impulsive source of $250 \mathrm{~kg}$, hitting vertically a steel square from a height of $3 \mathrm{~m}$, to generate compressional $(\mathrm{P})$ waves; two symmetric pendulum hammers, hitting horizontally a steel rectangular base pressed vertically against the soil, to produce horizontally polarized shear waves $(\mathrm{SH})$.

The seismic sources triggered a data recording system measuring the travel time of the wave train from sources to receivers. The deep DH receivers consisted of three uniaxial, one vertical and two horizontal, $10 \mathrm{~Hz}$ geophones. Seven $14 \mathrm{~Hz}$ geophones, three vertical and four horizontal, were placed at the surface, to support

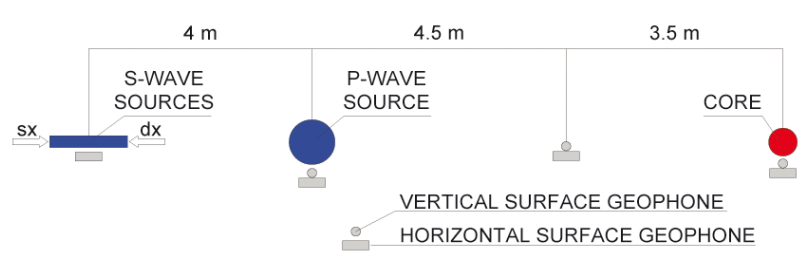

Figure 3. Schematic plan layout of the down hole seismic investigation. 


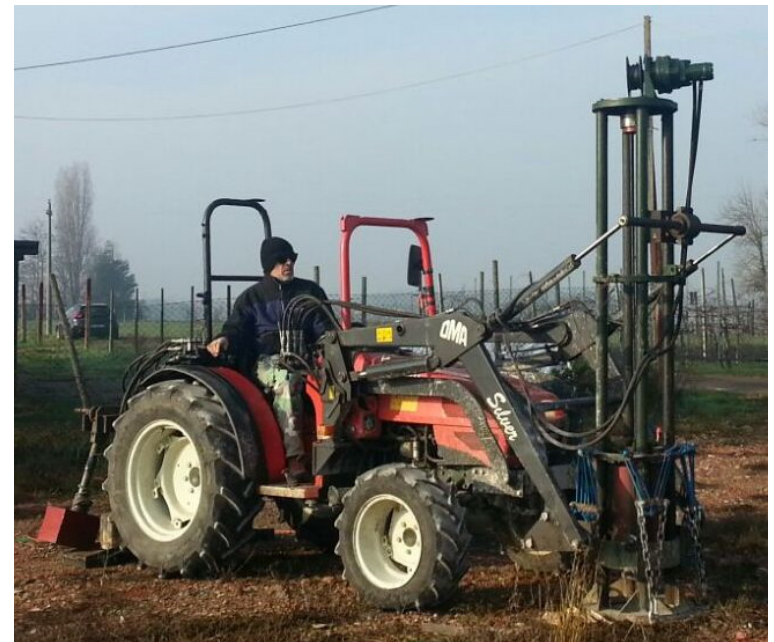

Figure 4. The three sources of seismic waves energized at the surface (see text)

the rephasing correction to the recorded DH seismograms. The system recorded 2000 samples, at a sampling time interval of $0.5 \mathrm{~m} / \mathrm{s}$. The $\mathrm{P}$ and $\mathrm{S}$ waves arrival time was interpreted according to ASTM D7400-14 [2014]. The DH Deep data were acquired from the depth of $18 \mathrm{~m}$ down to $265 \mathrm{~m}$, because of the steel casing of the uppermost part of core. An estimation of the $V_{S}$ in the uppermost $18 \mathrm{~m}$ was derived from the closest down-hole sounding, the DH M1 (Figure 1). The latter sounding was performed in 2012 by the Regione Emilia-Romagna, about $2800 \mathrm{~m}$ to the north-east of the $\mathrm{DH}$ deep site. The two adjacent logs are in good agreement in the shared $18-30 \mathrm{~m}$ stratigraphic interval and therefore a reasonable level of confidence can be estimated for the interpolation of the upper $18 \mathrm{~m}$ of the study log. Figure 5 provides the seismograms acquired at the $265 \mathrm{~m}$ depth, produced by the vertical hammer blow (black line "P-wave shot") and by the horizontal

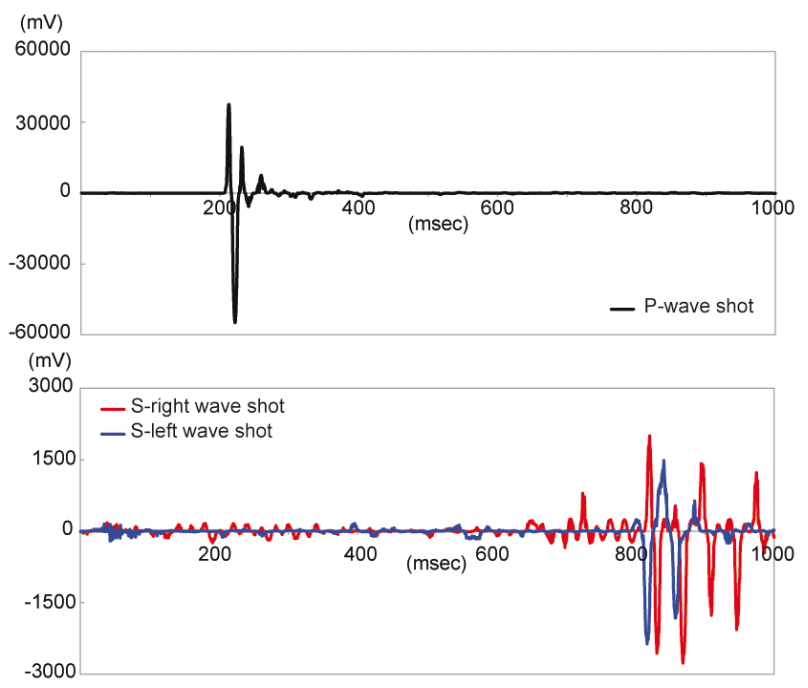

Figure 5. Seismograms acquired at $265 \mathrm{~m}$ from the DH deep test (Figure 6a). hammer blows striking the anvil on the two opposite sides (red line "S-right wave shot" and blue line "S-left wave shot"). The acquired stratigraphic and geophysical data are illustrated by Figure 6 .

\section{Stratigraphy and seismic velocities}

The stratigraphic succession logged in Mirabello was correlated with the $V_{P}$ and $V_{S}$ profiles plotted over depth at the same site (Figure 6a). The velocity logs acquired in Mirandola [Martelli and Romani 2013, Garofalo et al. 2016] were associated with our stratigraphic interpretation (Figure 6b) of the published lithology $\log$ [Regione Emilia-Romagna et al. 1998, Martelli and Romani 2013], based on our direct examination of the sediment cores and the knowledge of the regional stratigraphy framewok.

The correlation of successions drilled at Mirabello and Mirandola were based on published information, mainly deriving from the national geological mapping project (CARG) [Cibin and Segadelli 2009] and from regional geological profiles [Martelli and Romani 2013]. The logs provided also some dating evidence, particularly through ${ }^{14} \mathrm{C}$ analysis from the younger intervals. Several continuously cored logs were studied in proximity of the Mirabello drilling site, within the framework of the geological mapping project [Cibin and Segadelli 2009]. Particularly useful was the comparative analysis of the $\log 203 /$ S9, providing an allostratrigraphic framework of the sedimentary succession to the depth of $220 \mathrm{~m}$ and reaching the Lower EmilianoRomagnolo Synthem. The succession crossed by the core 203-S9 shows thicker correlative stratigraphic units than that revealed by the Mirabello drilling (203/S9 unit bases: AES8 21 m, AES7 68 m, AES6 98 m, AESi 187 m). From the core 203/S9, significant palaeo-environmental and micropalaeontological data were derived [Fiorini and Colalongo 2009]. The stratigraphic interpretation and dating of the upper portion of the study drilling was improved by the correlation with other two adjacent logs, the 203-S6 and the 203-S13 (Figure 1) reaching the depth of 34 and $68 \mathrm{~m}$ respectively. The correlation with the section cored at Mirandola has been based on our direct sedimentological and stratigraphical examination of the continuous cores, on the published lithological logs [Martelli and Romani 2013], and on the correlation with published stratigraphic profiles [Pao-lucci et al. 2015].

The regional correlation demonstrates that the Mirabello drilling crossed the entire Upper Emiliano-Romagnolo Synthem and Lower Emiliano Romagnolo Synthem and a large portion of the Marine Quaternary. Within the succession, each subsynthem has an average thickness of about $35 \mathrm{~m}$ and shows a similar internal organization. The drilled succession records a globally shal- 


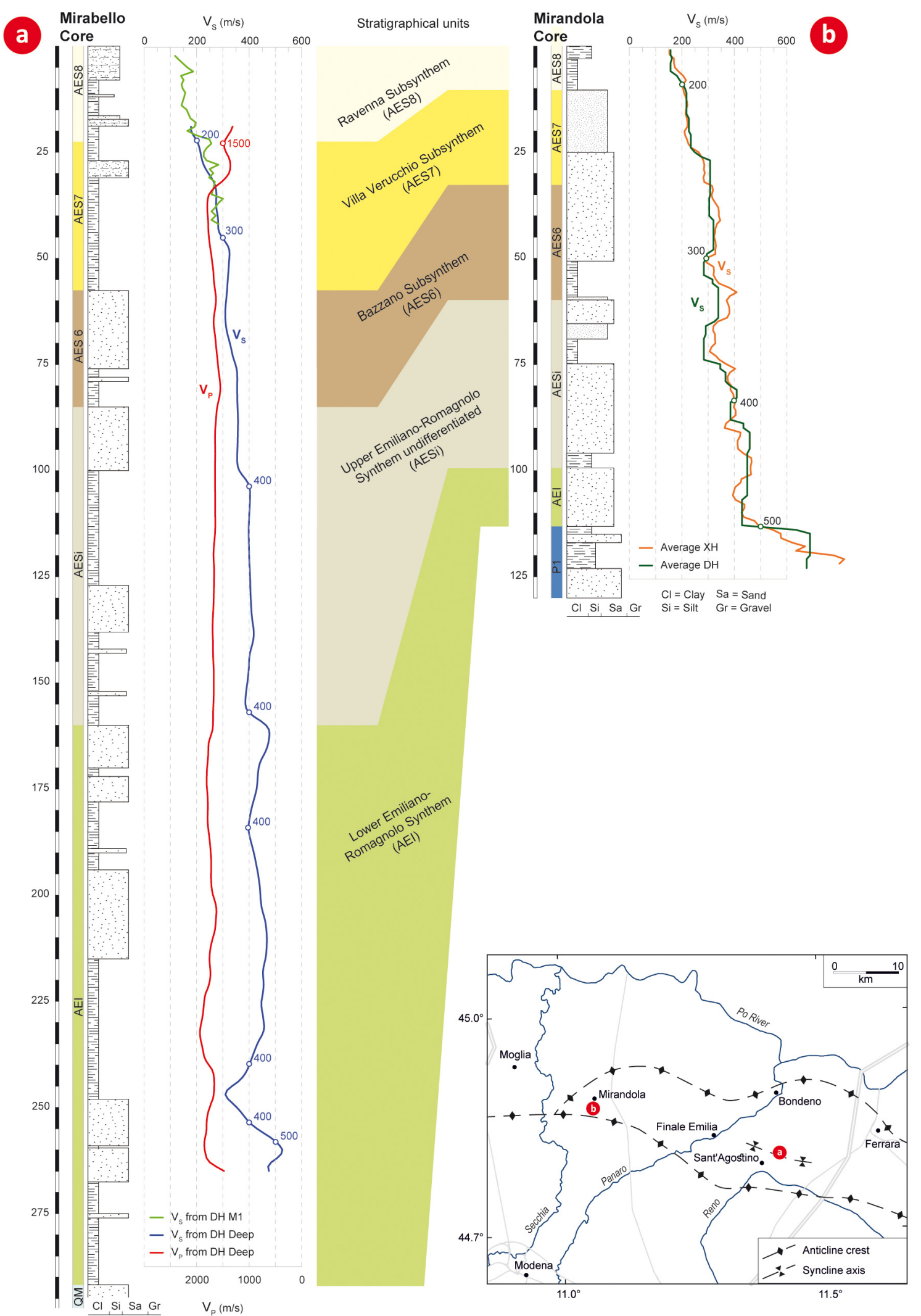

Figure 6. Stratigraphic column and seismic velocity logs from the Mirabello (a) and Mirandola (b) sites. The map shows the location of the two log sites and a schematic representation of the main syncline and anticline axis in the region.

lowing evolution, from marine environments to alluvial plain systems, spanning over a time period of roughly 600,000 years.

The stratigraphic organization correlates with the measured velocity values. The $V_{P} \log$ (Figure 6a) con- firms the presence of fully water saturated deposits between $18 \mathrm{~m}$ and $265 \mathrm{~m}$, providing an average value of $1500-2000 \mathrm{~m} / \mathrm{s}$ through the investigated depth. The $V_{S}$ increases gradually with depth, from $116-200 \mathrm{~m} / \mathrm{s}$, in the Ravenna Subsynthem, to $310-525 \mathrm{~m} / \mathrm{s}$, in the Lower 
Emiliano-Romagnolo Synthem (Table 1).

In the Mirabello succession, the Ravenna Subsynthem AES8 frames the first $22 \mathrm{~m}$ of subsoil and consists of outcropping Reno river sands, soft organic-rich marsh muds, with very low $S$-wave velocities, and older pedogenized continental silts, showing comparatively higher $V_{S}$ values. Fine-grained sediments dominate the Villa Verrucchio Subsynthem AES7 (23-58 m), associated with some fluvial sand intercalations, deposited by Apennine rivers. The AES7 unit top is associated with a sharp increase of the $S$-wave velocities, while at the lower portion of the unit a further $V_{S}$ increase is recorded, probably associated to pedogenized levels enriched in carbonate concretions. Thick bodies of fluvial sands deposited by the Po River [Cibin and Segadelli 2009] dominate the Bazzano Subsynthem AES6 (59-85 m), but finer-grained sediments are nevertheless well developed in the lower portion of the unit. The underlying AESi unit (86-162 m) consists of two transgressive-regressive cycles, separated, at about $127 \mathrm{~m}$, by a transgressive surface. Foraminifera, palecypod bioclasts and gastropods (Turritella) were sampled from the marine portions of the unit. The lower part of the upper cycle (105-127 m) is associated to a further increase of the S-wave velocity. At about $161 \mathrm{~m}$, the study well crossed the top of the AEI Synthem. The synthem consists of thick sandy or argillaceous bodies, deposited into marine, deltaic and alluvial plain environments. The fine-grained unit below $210 \mathrm{~m}$ correlates with a marine interval preserving infralittoral zone foraminifera [Fiorini and Colalongo 2009]. The unconformity marking the unit top correlates with a sharp increase of the $V_{S}$ values, almost reaching $500 \mathrm{~m} / \mathrm{s}$. Few further peaks of $V_{S}$ are associated to underlying thick layers of sand (160-165 $\mathrm{m}$ and 255-260 m). The AEI unit contains biogenic methane that could have affected the lowering of both $V_{P}$ and $V_{S}$ values, at depths between 235 and $260 \mathrm{~m}$.

The correlative anticline succession of Mirandola is much thinner than the Mirabello one. From the previously described correlation, we can confidently assume that AES unit is about $100 \mathrm{~m}$ thick, is enriched in fluvial sands, and lacks any marine influence. The succession nevertheless records S-wave velocity trends and values [Garofalo et al. 2016] similar to the Mirabello ones (Table 1, Figure 6a). The correlation between the AEI unit in Mirabello and the pebbly sands drilled at Mirandola (Figure 6b) below $100 \mathrm{~m}$, showing clasts of Palaeozoic acidic volcanites with porphyric structures, is uncertain. The lowermost portion of the Mirandola succession, underlying a sharp unconformity surface, was ascribed to the Lower Pliocene [Paolucci et al. 2015, Tarabusi and Caputo 2016]. This unit consists of lithified turbiditic sands, clays and marls, deposited into deep

\begin{tabular}{ccc}
\hline Unit & Mirabello & Mirandola \\
\hline AES8 & $116-200(161)$ & $158-213(174)$ \\
AES7 & $207-326(281)$ & $218-308(251)$ \\
AES6 & $310-356(334)$ & $284-339(312)$ \\
AESi & $355-464(394)$ & $284-460(375)$ \\
AEI & $310-525(434)$ & $430-449(439)$ \\
\hline
\end{tabular}

Table 1. $V_{S}$ values $(\mathrm{m} / \mathrm{s})$ measured within correlative stratigraphic units in the syncline site of Mirabello (Figure 6a) and in the anticline succession of Mirandola (Figure 6b). For each stratigraphic interval, the lowest, highest, and average values are indicated.

marine environments, and shows the highest $V_{S}$ values, above $600 \mathrm{~m} / \mathrm{s}$ [Garofalo et al. 2016]. These are the highest values recorded from the study successions, but they are still lower than the values officially assumed for the "seismic bedrock" [EN 1998-5 2004, NTC 2008].

\section{Discussions and conclusions}

The deep down-hole test performed in Mirabello, reaching a depth of more than $250 \mathrm{~m}$ below surface, has provided a unique deep seismic log from a tectonic active syncline area of the Apennine Foredeep Basin. No direct $V_{S}$ measurements deeper than $50 \mathrm{~m}$ were previously available in the syncline areas affected by the 2012 Emilia earthquakes. The new log, integrated by the correlation with the previous logs available in the region, supports a well constrained seismo-stratigraphic model of the interval spanning from the Lower Emiliano-Romagnolo Synthem to the Recent outcropping sediments (Figure 6). A good correlation is visible between the shear wave velocity distribution and the stratigraphic organization of the depositional succession. Stratigraphic discordance surfaces are related to sharp increases in the $V_{S}$ values, particularly at the boundary between the Lower and Upper Emiliano-Romagnolo Synthems. The logs from the syncline area of Mirabello was correlated with the thinner succession of Mirandola, deposited into an anticline area. Mirandola was the only site in the Emilia-Romagna Region where direct $V_{S}$ measurements were previously available from a deep level, and where down-hole and cross hole tests were performed and validated by different international research groups [Garofalo et al. 2016].

Correlatable units in the Mirabello and Mirandola boreholes show very similar S-wave velocity trends and values (Table 1, Figure 6a,b). The good agreement confirms the reliability of the deep down-hole interpretation at the Mirabello site. The small variations detectable between the two logs can be explained considering both the variation in sedimentary facies and lithologies and the different effective stresses of the Mirabello and Mirandola subsoils. The stronger compaction affecting the 
deeper argillaceous intervals at Mirabello influences the development of $V_{S}$ values similar to those recorded in correlative coarser grained intervals preserved at shallower level in the Mirandola succession.

The average seismic values recorded in Mirabello can be extrapolated with some confidence to the widespread syncline successions, through large portions of the alluvial plain. The new dataset here provided can support the definition of the input parameters for the seismic response analyses in similar Emilia-Romagna stratigraphic context, characterized by the absence of deep $V_{S}$ profile and the presence of a deep seismic bedrock.

Neither the Mirabello log nor the Mirandola one reached a $V_{S}$ value of $800 \mathrm{~m} / \mathrm{s}$, which officially defines the "seismic bedrock" into the European Building Code [EN 1998-5 2004] and the Italian building code [NTC 2008]. Some extra investigation, based on indirect surface approaches, as large 2D passive seismic arrays [e.g. Di Giulio et al. 2016], can be useful to obtain deeper velocity profiles, which, even if less accurate [Garofalo et al. 2016], will integrate the provided direct seismic velocity measures, supporting a better constrained and more reliable ground response analysis.

Acknowledgements. Special thanks to the Protezione Civile, to the Regione Emilia-Romagna, and to the Mirabello Municipality, for funding the seismic microzonation of Mirabello. We thank also Luca Martelli and Paolo Severi (Emilia-Romagna Region) for providing data from the Emilia-Romagna geological database, and Ferruccio Laurenti for providing the access to the site of the Mirabello deep borehole.

\section{References}

ASTM D7400-14 (2014). Standard Test Methods for Downhole Seismic Testing, ASTM International.

Bigi, G., G. Bonardini, R. Catalano, D. Cosentino, F. Lentini, M. Parlotto, R. Sartori, P. Scandone and E. Turco (1992). Structural model of Italy, 1:500.000, Edizioni Consiglio Nazionale delle Ricerche, Rome.

Boccaletti, M., M. Bonini, G. Corti, P. Gasperini, L. Martelli, L. Piccardi, C. Tanini and G. Vannucci (2004). Seismotectonic Map of the Emilia-Romagna Region, 1:250000, Regione Emilia-Romagna, Consiglio Nazionale delle Ricerche.

Bonini, L., G. Toscani and S. Seno (2014). Three-dimensional segmentation and different rupture behavior during the 2012 Emilia seismic sequence (Northern Italy), Tectonophysics, 630, 33-42; doi:10. 1016/j.tecto.2014.05.006.

Caputo, R., and G. Papathanasiou (2012). Ground failure and liquefaction phenomena triggered by the 20 May, 2012 Emilia-Romagna (Northern Italy) earthquake: case study of Sant'Agostino - San Carlo Mirabello zone, Natural Hazards and Earth System
Sciences, 12 (11), 3177-3180; doi:10.5194/nhess-123177-2012.

Carminati, E., D. Scrocca and C. Doglioni (2010). Compaction-induced stress variations with depth in an active anticline: Northern Apennines, Italy, Journal of Geophysical Research: Solid Earth, 115, B02401; doi:10.1029/2009JB006395.

Cibin, U., and S. Segadelli, eds. (2009). Note Illustrative della Carta Geologica d'Italia alla scala 1/50000, Foglio 203 Poggio Renatico. ISPRA, Servizio Geologico d'Italia, 104 p. (in Italian).

Di Giulio, G., R. de Nardis, P. Boncio, G. Milana, G. Rosatelli, F. Stoppa and G. Lavecchia (2016). Seismic response of a deep continental basin including velocity inversion: the Sulmona intramontane basin (Central Apennines, Italy), Geophysical Journal International, 204, 418-439; doi:10.1093/gji/ggv444.

Di Manna, P., L. Guerrieri, L. Piccardi, E. Vittori, D. Castaldini, A. Berlusconi, L. Bonadeo, V. Comerci, F. Ferrario, R. Gambillara, F. Livio, M. Lucarini and A.M. Michetti (2012). Ground effects induced by the 2012 seismic sequence in Emilia: Implications for seismic hazard assessment in the Po Plain, Annals of Geophysics, 55 (4), 697-703; doi:10.4401/ag-6143.

DISS Working Group (2015). Database of Individual Seismogenic Sources (DISS), Version 3.2.0: A compilation of potential sources for earthquakes larger than M 5.5 in Italy and surrounding areas; http:/ / diss. rm.ingv.it/diss/; doi:10.6092/INGV.IT-DISS3.2.0.

Emergeo Working Group (2013). Liquefaction phenomena associated with the Emilia earthquake sequence of May-June 2012 (Northern Italy), Natural Hazards and Earth System Sciences, 13 (4), 935-947; doi:10.5194/nhess-13-935-2013.

EN 1998-5 (2004). Eurocode 8: Design of structures for earthquake resistance - Part 5: Foundations, retaining structures and geotechnical aspects, CEN European Committee for Standardization, Bruxelles, Belgium.

Fiorini, F., and M.L. Colalongo (2009). Micropaleontologia del sondaggio 203-S9, In: U. Cibin and S. Segadelli (eds.), Note Illustrative della Carta Geologica d'Italia alla scala 1/50000, Foglio 203 Poggio Renatico, ISPRA, Servizio Geologico d'Italia, 104 p. (in Italian).

Garofalo, F., S. Foti, F. Hollender, P.Y. Bard, C. Cornou, B.R. Cox, A. Dechamp, M. Ohrnberger, V. Perron, D. Sicilia, D. Teague and C. Vergniault (2016). InterPACIFIC project: Comparison of invasive and non-invasive methods for seismic site characterization. Part II: Inter-comparison between surface wave and borehole methods, Soil Dynamics and Earthquake Engineering, 82, 241-254; doi:10.1016/j.soil 
dyn.2015.12.009.

GeoMol Team (2015). GeoMol - Assessing subsurface potentials of the Alpine Foreland Basins for sustainable planning and use of natural resources - Project Report, Augsburg, LfU, 188 p.

Ghielmi, M., M. Minervini, C. Nini, S. Rogledi and M. Rossi (2013). Late Miocene-Middle Pleistocene sequences in the Po Plain - Northern Adriatic Sea (Italy): The stratigraphic record of modification phases affecting a complex foreland basin, Marine and Petroleum Geology, Special Issue: The Geology of the Periadriatic Basin and of the Adriatic Sea, 42, 50-81; doi:10.1016/j.marpetgeo.2012.11.007.

Malagnini, M., R.B. Herrmann, I. Munafò, M. Buttinelli, M. Anselmi, A. Akinci and E. Boschi (2012). The 2012 Ferrara seismic sequence: Regional crustal structure, earthquake sources, and seismic hazard, Geophysical Journal International, 39 (19); doi:10.10 29/2012GL053214.

Martelli, L., and M. Romani (2013). Microzonazione sismica e analisi della condizione limite per l'emergenza delle aree epicentrali dei terremoti della pianura emiliana di maggio-giugno 2012 (Ordinanza del commissario delegato n. 70/2012), Relazione Illustrativa (in Italian); http: / / ambiente.regione.emi lia-romagna.it/geologia/archivio_pdf/sismica/MS ord70_relazione.pdf/at_download/file/MSord70_re lazione.pdf.

Martinson, D.G., N.G. Pisias, J.D. Hays, J. Imbrie, T.C. Moore and N.J. Shackleton (1987). Age dating and the orbital theory of the ice ages: Development of a high-resolution 0 to 300,000-year chronostratigraphy, Quaternary Research, 27 (1), 1-29.

Meletti, C., V. D’Amico, G. Ameri, A. Rovida and M. Stucchi (2012). Seismic hazard in the Po Plain and the 2012 Emilia earthquakes, Annals of Geophysics, 55 (4), 623-629; doi:10.4401/ag-6158.

Milana, G., P. Bordoni, F. Cara et al. (2014). 1D velocity structure of the Po River plain (Northern Italy) assessed by combining strong motion and ambient noise data, Bulletin of Earthquake Engineering, 12, 2195; doi:10.1007/s10518-013-9483-y.

NTC (2008). Norme tecniche per le costruzioni, Ministero delle Infrastrutture e dei Trasporti, Decreto Ministeriale del 14 gennaio 2008, Supplemento ordinario alla Gazzetta Ufficiale n. 29 del 4 febbraio 2008 (in Italian).

Paolucci, E., D. Albarello, S. D’Amico, E. Lunidei, L. Martelli, M. Mucciarelli and D. Pileggi (2015). A large scale ambient vibration survey in the area damaged by May-June 2012 seismic sequence in Emilia Romagna, Italy, Bulletin of Earthquake Engineering, 13 (11), 3187-3206.
Papathanassiou, G., R. Caputo and D. Rapti-Caputo (2012). Liquefaction phenomena along the paleoReno River caused by the May 20, 2012, Emilia (northern Italy) earthquake, Annals of Geophysics, 55 (4), 735-742; doi:10.4401/ag-6147.

Papathanassiou, G., A. Mantovani, G. Tarabusi, D. Rapti and R. Caputo (2015). Assessment of liquefaction potential for two liquefaction prone areas considering the May 20, 2012 Emilia (Italy) earthquake, Engineering Geology, 189, 1-16; doi:10.1016/j.enggeo. 2015.02.002.

Pieri, M., and G. Groppi (1981). Subsurface geological structure of the Po Plain, Italy, Consiglio Nazionale delle Ricerche, Progetto finalizzato Geodinamica, sottoprogetto Modello Strutturale, pubbl. n. 414, Rome, 13 p. (in Italian).

Pondrelli, S., S. Salimbeni, P. Perfetti and P. Danecek (2012). Quick regional centroid moment tensor solutions for the Emilia 2012 (northern Italy) seismic sequence, Annals of Geophysics, 55 (4), 615-621; doi:10.4401/ag-6146.

Regione Emilia-Romagna, Servizio Geologico Sismico e dei Suoli, ENI-AGIP (1998). Riserve idriche sotterranee della Regione Emilia-Romagna, scala 1:250.000, Bologna.

Tarabusi, G., and R. Caputo (2016). The use of HVSR measurements for investigating buried tectonic structures: the Mirandola anticline, Northern Italy, as a case study, International Journal of Earth Sciences; doi:10.1007/s00531-016-1322-3.

Tonni, L., G. Gottardi, S. Amoroso, R. Bardotti, L. Bonzi, A. Chiaradonna, A. d'Onofrio, V. Fioravante, A. Ghinelli, D. Giretti, G. Lanzo, C. Madiai, M. Marchi, L. Martelli, P. Monaco, D. Porcino, R. Razzano, S. Rosselli, P. Severi, F. Silvestri, L. Simeoni, G. Vannucchi and S. Aversa (2015). Analisi dei fenomeni deformativi indotti dalla sequenza sismica emiliana del 2012 su un tratto di argine del Canale Diversivo di Burana (FE), Rivista Italiana di Geotecnica, Pàtron Editore, Bologna, Anno XLIX, n. 2, 28-38; ISSN 0557-1405.

Vannoli, P., P. Burrato and G. Valensise (2015). The seismotectonics of the Po Plain (Northern Italy): tectonic diversity in a blind faulting domain, Pure and Applied Geophysics, 172, 1105-1142; doi:10.1007/s0 0024-014-0873-0.

\footnotetext{
*Corresponding author: Luca Minarelli, Geotema srl, University of Ferrara spin-off company, Ferrara, Italy; email: minarelli@geotema.it.

(C) 2016 by the Istituto Nazionale di Geofisica e Vulcanologia. All rights reserved.
} 